BIO-CONS, Jurnal Biologi \& Konservasi

Volume 3 No. 2, Desember 2021

p-ISSN : 2620-3510, e-ISSN: 2620-3529

\title{
APPLICATION OF GANDASIL D FERTILIZER ON THE FRESHNESS OF CHRYSANTHEMUM FLOWERS IN HYDROGEL MEDIA
}

\author{
Yusra, Fatimatuz Zuhro*, Sarwo Danuji \\ PGRI Argopuro University, Jember \\ Jl. Jawa Nomor 10 Sumbersari-Jember, Indonesia \\ *Email: bundafatim@gmail.com
}

\begin{abstract}
Chrysanthemum sp. is one of the popular types of cut flowers and is in great demand by consumers because of its attractive shape, color, and varying sizes. This study aims to determine the effect of Gandasil D and its application method in maintaining the freshness of chrysanthemum flowers in hydrogel media. This study used a completely randomized design consisting of 2 treatment factors, namely the concentration treatment of Gandasil D $(0 \%, 0.5 \%$, and $1 \%)$ and the application of Gandasil D (soaking, spraying, and a combination of both). Parameters observed, among others; leaf wilting rate, flower freshness duration, leaf freshness duration, and flower wilting rate. The results of this study showed that the concentration of Gandasil D treatment had no significant effect on the freshness of chrysanthemum flowers, except for the length of leaf freshness parameter which showed that the concentration of Gandasil D 1\% produced the longest leaf freshness among other treatments. The Gandasil D application method has a significant effect on the freshness of chrysanthemums. The single treatment of immersion or spraying resulted has a longer average flower freshness than the combination treatment, although the average value between soaking and spraying was not significant. The combination of concentration treatment and application method of Gandasil D had no significant effect on the freshness of chrysanthemums, except for the length of flower freshness parameter.
\end{abstract}

Keywords: Chrysanthemum sp, Gandasil D, Hydrogel. 


\section{INTRODUCTION}

Chrysanthemum sp. is a flower belonging to the compositae family originating from China. Since ancient times, chrysanthemums are cultivated to produce cut flowers. The specialty of chrysanthemum flowers apart from many fans, namely the various shapes and types, the color of the flowers also varies, with the combination of different colors that are so beautiful with relatively long freshness and easy to assemble, the flowering and harvesting can be arranged according to market prices (Listyani, 2013). Chrysanthemum flowers also have advantages compared to other types of cut flowers such as gladiolus, kerkrily, hebras, daisies, roses, and carnations, and also resistant to the touch of volcanic volcanic dust (Pangemanan et al, 2011).

The increasing number of requests for chrysanthemums lately has encouraged efforts to maintain the freshness of chrysanthemums, so that they can last longer in flowering and fresh conditions. Nento (2017) states that flower quality is one of the problems often faced by cut flower entrepreneurs and consumers, because high quality flowers will give the beauty and freshness of cut flowers, so that they can be enjoyed for a longer time.

An alternative planting medium that can be used to maintain the freshness of chrysanthemums is hydrogel media. Hydrogel is a polymer technology product that has a threedimensional structure that is able to absorb or release water based on external stimulants (Adi, 2012). In addition, the hydrogel media visually looks attractive, clean, and good if you make ornamental plant media in restaurants, living rooms, or even work desks. Hydrogel media can be used as an alternative medium to replace soil, gravel, or sand. In general, hydrogels can absorb at least 10-20 percent of the total amount of water present (Ayuningtyas, 2012). However, plants that are suitable for placing in hydrogel media are mostly limited to leafy ornamental plants, for example aglonema, sri fortune, pride of sumatra, lady valentine, mother-in-law's tongue, lorentii, masonia, anthorium, wave of love, hookery, elephant ears, yellow bamboo mini, Japanese bamboo, red betel, Dutch betel, and types of ferns and plants that like high humidity (Rahman, 2015).

The use of hydrogel media as a planting medium for flowering ornamental plants has not been widely used. This is because ornamental plants are less able to last long when placed in hydrogel media. The application of fertilizers as additional nutrients in hydrogel media is thought to increase the resistance of flowering ornamental plants. One of the fertilizers that can be used on hydrogel media is gandasil D fertilizer (Bortan Asty, 2013). Gandasil D is a complete foliar fertilizer, in the form of crystals that dissolves in water quickly (Palemba, 2013). The addition of Gandasil D aims to maintain the continuity of the chrysanthemum flower organ, because it functions as an additional nutrient in the hydrogel media, so that the freshness of the chrysan- 
themum flowers in the hydrogel medium lasts for a matter of months. Therefore, the author took the initiative to conduct research with the aim of increasing the freshness of chrysanthemum flowers in hydrogel media with the application of Gandasil D fertilizer.

\section{METHOD}

\section{Tools and Materials}

The tools used in this study were glass bottles, cutters, rulers, measuring cups and analytical balances, while the materials used in this study were white chrysanthemums, hydrogel and gandasil D fertilizer.

\section{Research Design}

The type of this research is an experimental study, using a factorial Completely Randomized Design (CRD) consisting of 2 factors. The first factor is the concentration of Gandasil D fertilizer $(0 \%, 0.5 \%$, and $1 \%)$, while the second factor is the application method of Gandasil D (soaking, spraying and a combination of the two). The treatment was repeated 4 times, so that a total of 36 experimental units were obtained.

\section{Research Procedure}

\section{How to Use Hydrogel}

a. Soaking 2 grams of hydrogel in a solution containing gandasil D for 8 hours.

b. Move the finished hydrogel granules, then drain the water content.

c. Transferring the hydrogel to a glass bottle to be used as a planting medium

\section{Gandasil D Application}

a. Immersion treatment: dissolve Gandasil D in 1 liter of water with a predetermined concentration, then the solution is made to soak the hydrogel.

b. Spraying treatment: dissolve Gandasil D in 1 liter of water, then the solution is sprayed on the flowers and leaves according to the predetermined concentration.

c. Combination treatment: Dissolve Gandasil D in 1 liter of water with a predetermined concentration, then spray Gandasil D on flowers and leaves according to the concentration of treatments. 


\section{Parameters}

The parameters observed in this study were divided into 2 groups, namely:

a. Leaf wilting rate.

Indicators: 1 . The petals are drooping down

2. There is a change in color

b. Length of freshness of flowers (crown)

Indicator: 1. Brilliant color

2. Flower eyes expand

3. Crown opens up to $90^{\circ}$

c. The duration of freshness of the leaves

Indicator: 1. Brilliant color

d. Flower withering rate (crown)

Indicators: 1 . The flower crown closes (wrinkles) and curls inward

2. The appearance of discoloration on the crown

\section{Data Analysis}

Data analysis of research begins with homogeneity and normality tests. If the data are normal and homogeneous, then the data will be analyzed by the Anova test, followed by Duncan's further test at an error of $5 \%$. 


\section{RESULTS AND DISCUSSION}

Data analysis in this study produced information as shown in Table 1. below.

Table 1. Results of Anova Test and Duncan Advanced Test of Gandasil D Application on Chrysanthemum Flower Freshness

\begin{tabular}{llccc}
\hline \multirow{2}{*}{ Parameters } & Treatments & \multicolumn{3}{c}{ Average (Days) } \\
\cline { 3 - 5 } & & $0 \%$ & $0,5 \%$ & $1 \%$ \\
\hline Leaf wilting rate & Soaking & $6.25 \mathrm{aB}$ & $6.00 \mathrm{aB}$ & $6.25 \mathrm{aB}$ \\
& Spraying & $6.50 \mathrm{aB}$ & $6.75 \mathrm{aB}$ & $6.75 \mathrm{aB}$ \\
& Combination & $4.00 \mathrm{aA}$ & $4.50 \mathrm{aA}$ & $3.75 \mathrm{aA}$ \\
Flower freshness duration & Soaking & $8.25 \mathrm{aB}$ & $8.50 \mathrm{aB}$ & $8.25 \mathrm{aB}$ \\
& Spraying & $8.25 \mathrm{aB}$ & $8.00 \mathrm{aB}$ & $7.75 \mathrm{aB}$ \\
& Combination & $3.00 \mathrm{aA}$ & $3.50 \mathrm{aA}$ & $4.50 \mathrm{aA}$ \\
& Soaking & $5.25 \mathrm{aB}$ & $5.25 \mathrm{aB}$ & $6.25 \mathrm{bB}$ \\
Leaf freshness duration & Spraying & $5.50 \mathrm{aB}$ & $5.75 \mathrm{aB}$ & $5.75 \mathrm{bB}$ \\
& Combination & $2.25 \mathrm{aA}$ & $2.00 \mathrm{aA}$ & $2.75 \mathrm{bA}$ \\
Flower wilting rate & Soaking & $9.50 \mathrm{aB}$ & $10.50 \mathrm{aB}$ & $10.00 \mathrm{aB}$ \\
& Spraying & $10.50 \mathrm{aB}$ & $10.00 \mathrm{aB}$ & $9.25 \mathrm{aB}$ \\
& Combination & $7.25 \mathrm{aA}$ & $8.00 \mathrm{aA}$ & $9.50 \mathrm{aA}$ \\
\hline
\end{tabular}

Description: Numbers followed by the same letter show no different results /non-significant. Capital letters are read horizontally (lines), and lowercase letters are read vertically (columns).

Based on Table 1., it can be seen that the Gandasil D concentration treatment in general had no significant effect on the freshness of chrysanthemum flowers, except for the leaf freshness parameter which showed that $1 \%$ Gandasil D concentration resulted in the longest leaf freshness among other treatments.

Meanwhile, the application of Gandasil D had a significant effect on the freshness of chrysanthemums. The results of the average length of freshness of chrysanthemums showed that the single treatment of soaking or spraying resulted in a longer average flower freshness than the combination treatment, although the average value between soaking and spraying was not significant. The combination of concentration treatment and the application method of Gandasil D had no significant effect on the freshness of chrysanthemums, except for the length of flower freshness parameter.

Age or length of freshness is the main determinant of cut flower quality which is calculated from the time the flowers are harvested until they wither or fall. The freshness of standard varieties of chrysanthemum cut flowers is indicated by the flower crowns open at a maximum of $135^{\circ} \mathrm{C}$ to the vertical line, the flower eyes begin to expand, the color is bright, and the stems are solid (Hidayah, 2012). 
The use of hydrogel as a medium for chrysanthemum cut flowers aims to prolong the freshness of the flowers (slows down the flower wilting process). Before being used as a medium, the hydrogel was first soaked. Cut chrysanthemum flowers must be conditioned to stay fresh because chrysanthemums are sensitive to dehydration, so the flowers must be soaked in water or in a pulsing solution.

Pulsing is the process of soaking flower stalks immediately after harvesting, which serves as a cut flower freshener for 2-24 hours (Soleman and Bobby, 2020). In this study, the immersion of chrysanthemum stalks was carried out on hydrogel media which had previously been soaked in a Gandasil D solution. The function of adding Gandasil D to chrysanthemum flowers was to provide a nutrient supply for the organs of leaves, stems and flower crowns so that they were expected to have a longer freshness. This is in accordance with the research of Andalasari, et al (2014) which stated that the addition of Gandasil D in the hydrogel was thought to be able to increase the ability of plant organs to retain water content. According to Wiraatmaja, et al (2007) the wilting process is accelerated when the water loss is more than the absorption, causing the flower stalk to lack water, the lower the water absorbed by the flower stalk, the higher the percentage of wilted flowers.

Soaking ingredients or flower fresheners play a role in prolonging the fresh period, increasing the size of blooming flowers, increasing flower buds that will bloom, maintaining flower color and slowing leaf drying. The research results of Hidayah et al. (2012) showed that the soaking solution is one of the elements that determines the freshness of flowers and the percentage of flower blooms during soaking.

In the results of this study, the combination treatment actually gave a less good effect on the freshness of chrysanthemum flowers than other single treatments (soaking and spraying). This can be caused because in the combination treatment too many nutrients are absorbed in the hydrogel media which causes the concentration of nutrients to be too concentrated. This can cause plasmolysis. This is in line with the results of research by Arisanti and Setiari (2012) which states that the high concentrations of vitamin $\mathrm{C}$ causes the soaking solution to be concentrated, causing greater osmotic pressure of the fluid outside the cell, then the fluid inside the cell will come out and result in plasmolysis. Plasmolysis that occurs causes the constituent cells in the chrysanthemum flower stalk to be damaged which can lead to the growth of bacteria and the formation of mucus on the flower stalk resulting in blockage, as a result the absorption of the soaking solution will be inhibited. The inhibition of the absorption of the solution caused the 
flowers to wilt quickly due to lack of water, so that the freshness of the chrysanthemum flowers decreased faster than the chrysanthemum flowers that were only soaked in water (control).

\section{CONCLUSION}

Based on the results of this study, it can be concluded that:

1. Treatment with Gandasil D concentration had no significant effect on the freshness of chrysanthemum flowers, except for the length of leaf freshness parameter which showed that the concentration of Gandasil D 1\% produced the longest leaf freshness among other treatments.

2. The application of Gandasil D has a significant effect on the freshness of chrysanthemums. The single immersion or spraying treatment resulted in a longer mean flower freshness than the combination treatment, although the average value between soaking and spraying was not significant.

3. The combination of concentration treatment and application method of Gandasil D had no significant effect on the freshness of chrysanthemums, except for the length of flower freshness parameter.

\section{REFERENCES}

Andalasari, T. D., Yafisham, dan Nuraini. (2014). Respon Pertumbuhan Anggrek Dendrobium terhadap Jenis Media Tanam dan Pupuk Daun. Jurnal Penelitian Pertanian Terapan, 14 (1): 76-82.

Arisanti, D., dan N. Setiari. (2012). Pengaruh Pemberian Vitamin C (asam askorbat) terhadap Kesegaran Bunga Krisan (Chrysanthemum Sp.) pada Kawasan Sentra Penghasil di Desa Ngasem, Kecamatan Jetis, Bandungan, Jawa Tengah. Buletin Anatomi dan Fisiologi, 20 (1), 37-46.

Ayuningtyas, F. (2012). Pembuatan dan Karakterisasi Beads Hidrogel dari Berbagai Polimer sebagai Media Tanam. Skripsi. Fakultas Matematika dan Ilmu Pengetahuan Alam Program Studi Paralel Departemen Farmasi. Depok.

Bortan Asty. (2013). Aplikasi Hidrogel (Online). http://unikdanmewah.blogspot.co.id/p/caraaplikasi-hidrogel.html. Di Akses tanggal 22 Agustus 2021.

Hidayah, A. F. D. S. (2012). Pengaruh Rebusan Daun Sirih (Piper Betle) pada Larutan Perendam terhadap Kesegaran Bunga Potong Krisan (Chrysanthemum Indicum L.). Skripsi. Universitas Jember. 
Listyani, N.G dan Widiawati D. S.Sn, M.Sn. (2013). Eksplorasi Bunga Krisan (Chrysantheum) sebagai Zat Pewarna Alami pada Kain Sutera untuk Produk Fashion. Jurnal Tingkat Sarjana Senirupa dan Desain, 1 (2), 1-9.

Nento, R., Tiwow, D.S., Demmassabu, S. L. (2017). Aplikasi Larutan Pengawet terhadap Kualitas Bunga Potong Krisan (Chrysanthemum Sp.). Cocos, 1 (1), 1-12.

Palemba, T. Y., M. T. Lasut, J. I. Kalangi, dan A. Thomas. (2013). Aplikasi Pupuk Daun Gandasil D terhadap Pertumbuhan Bibit Jabon Merah (Anthocephalus macrophyllus Havil). Cocos , 2(1), 1-10.

Pangemanan, L., G. Kapantaow, dan M. Watung. (2011). Analisis Pendapatan Usaha tani Bunga Potong (Studi Kasus Petani Bunga Krisan Putih di Kelurahan Kakaskasen Dua Kecamatan Tomohon Utara Kota Tomohon). ASE, 7 (2), 5-14.

Rahman, S. (2015). Tanaman Hias Tanpa Tanah (Hidrogel)_(Online). https://www.kompasiana.com/ipoelbungas/54f4b0f17455137c2b6c8cd7/tanaman-hiastanpa-tanah-hydrogel. Diakses pada 22 Agustus 2021.

Adi, S. H. (2012). Teknologi Nano Untuk Pertanian: Aplikasi Hidrogel Untuk Efisiensi Irigasi. Jurnal Sumberdaya Lahan, 6 (1), 1-8.

Soleman, A. Y. dan Bobby, J. V. P. (2020). Larutan Perendam (Pulsing) pada Bunga Potong Krisan. Jurnal Agroteknologi Terapan, 1 (1), 14-19.

Wiraatmaja, I. W., I Nyoman, G. A., dan Ni Nyoman, D. (2007). Memperpanjang Kesegaran Bunga Potong Krisan (Dendranthema Grandiflora Tzvelev.) dengan Larutan Perendam Sukrosa dan Asam Sitrat. Agritrop. 26 (3), 129 - 135. 